\title{
Kedisiplinan Siswa terhadap Objek Mata Pelajaran IPA di SMP Kabupaten Muaro Jambi
}

\author{
Nugroho Kurniawan ${ }^{1}$, Nurlaili ${ }^{2}$ \\ ${ }^{1}$ SIT Mutiara Hati, Tebo, Indoenesia \\ ${ }^{2}$ MAN Insan Cendikia Lampung Timur, Lampung, Indonesia
}

Article Info

\section{Article history:}

Received Mei 7, 2020

Revised Mei 21, 2020

Accepted Mei 26, 2020

\section{Keywords:}

Disiplin

Pembelajaran IPA

Siswa

\begin{abstract}
Tujuan penelitian: Guru merupakan tenaga pendidik yang prosfesional. Sebagai seorang tenaga yang profesional guru harus mampu menjadi fasilitator yang baik didalam kelas. Penelitian ini peran guru dalam meningkatkan pembelajaran IPA melalui pembelajaran berbasis Etnosains

Metodologi: Penelitian ini menggunakan metode eksperimen. Sumber data dalam penelitian ini yaitu kelas 5A dan 5B yang terdiri dari Kelas 5A berjumlah 25 orang yang terdiri dari 10 laki-laki dan 15 orang perempuan. Sedangkan kelas 5B berjumlah 24 orang yang terdiri dari 12 orang laki-laki dan 12 orang perempuan

Temuan utama: Hasil dari penelitian ini menunjukkan bahwa terjadi peningkatan pemahan siswa pada materi organ pernapasan hewan dan fungsinyya secara signifikan pada kelas ekperimen setelah pembelajaran dilakukan berbasis Etnosains.

Keterbaruan penelitian: penelitian ini memiliki keterbaruan pada bidang pembelajaran yang efektif dan efisin menggunakan basis Etnosains pada pembelajaran IPA disekolag dasar.
\end{abstract}

This is an open access article under the CC BY-NC license

\section{Corresponding Author:}

Nurlaili,

MAN Insan Cendikia Lampung Timur, Lampung

Email: nurlaili.ac114021@gmail.com

\section{PENDAHULUAN}

Era abad 21 menandakan aspek-aspek yang menjadi sendi kehidupan manusia mengalami percepatan yang sangat pesat. Salah satunya adalah pertumbuhan dan pembaruan yang dinamis pada dunia pendidikan. Sehingga pendidikan menjadi tumbuh secara pesat dan melekat pada setiap individu. Tanpa pendidikan, seorang individu akan sulit berpartisipasi aktif dalam era globalisasi dan menemukan kesulitan untuk meraih kesempatan yang lebih baik [1]. Dengan demikian, setiap siswa berhak untuk memperoleh pendidikan berkualitas \& baik. Pendidikan bertujuan untuk memberikan pengetahuan yang positif bagi setiap individu. pendidikan adalah kegiatan yang sangat penting dan sebagai proses pengembangan untuk individu, melalui pendidikan setiap individu mampu mengubah pengetahuam dan perilaku setiap individu menhadi lebih baik [2].

Pendidikan dalam kegiatan proses belajar mengajar yang umunya menjadi objek pembahasan adalah kemampuan siswa dalam menguasai atau memahami konsep materi pelajaran. Hal itu dibuktikan sebagaimana di sekolah-sekolah diajarkan berbagai subjek materi pelajaran yang memiliki rumpun ilmu dari; ilmu alam (eksakta), ilmu sosial, ilmu olahraga dan kesehatan, maupun ilmu yang berhubungan dengan IT (Informasi dan Teknologi). Salah satu fokus materi pelajaran yang dibahas untuk saat ini adalah mata 
pelajaran IPA (Ilmu Pengetahuan Alam) di tingkat Sekolah Menengah Pertama (IPA). Pendidikan IPA merupakan suatu upaya dalam proses memberikan pembelajaran kepada setiap peserta didik (siswa) dengan tujuan siswa mampu menguasai dan memahami hakikat IPA [3]. IPA merupakan Ilmu pengetahuan alam yang mempelajari objek ddan proses yang terjadi di alam [4].

Akan tetatpi kegiatan pembelajaran tidak melulu tentang bagaiaman melengkapi dan meningkatkan aspek kognitif saja. Ada aspek yang juga harus dipenuhi, salah satunya adalah aspek karakter (afektif siswa). Aspek ini diyakini mampu mendorong efektivitas dan keberhasilan pembelajaran siswa. Karakter merupakan kumpulan dari tingkah laku baik dari seorang individu [5]. Setiap Peserta didik (individu siswa) sangat penting memiliki aspek karakter positif dalam dirinya untuk dikembangkan dan diimplemntasi ke segala hal perbuatan. Salah satu karakter yang secara positif dapat mendukung siswa dalam kegiatan pembelajaran adalah disiplin. Disiplin diri adalah suatu siklus kebiasaan yang dilakukan berulang-ulang dan terus menerus secara berkesinambungan dan konsisten (Saleh, 2012). Sehingga disiplin sangat penting diterapkan terhadap objel pembelajaran, karena berdampak positif terhadap kebiasaan baik siswa terhadap objek pembelajaran tersebut.

Salah satu penerapan kedisiplinan dapat diterapkan pada mata pelajaran IPA. Hal ini bermanfaat dalam mendeteksi bagaimana sikap dan perilaku disiplin siswa terhadap IPA tak terbatas hanya di lingkungan Sekolah. Disiplin siswa terhadap IPA dapat didefinisikan sebagai suatu upaya yang baik dan konsisten dalam melaksanakan kegiatan pembelajaran IPA maupun kegiatan lainnya secara teratur dan sistematis [6]. Terdapat suatu pengaruh positif pada disiplin terhadap pembelajaran IPA. Oleh karena itu sangat penting dilaksanakan pembelajaran IPA dengan selaras menerapkan kedisiplinan bagi setiap siswa [7].

Salah satu alasan kenapa pembelajaran IPA harus diberikan treatment atau perlakuan khusus karena masih banyak anggapan berupa data fakta maupun asumsi yang menyatakan bahwa pelajaran IPA pembelajaran yang terlalu kompleks susunan materinya sehingga menyulitkan bagi siswa. pembelajaran IPA khususnya materi fisika sebagian besar disajikan sebagai konsep dan kumpulan rumus yang harus dihafalkan [8]. Pembelajaran IPA di sekolah masih menjadi pembelajaran yang sulit untuk sebagian siswa [9]. Dari hasil wawancarannya dengan guru IPA menyatakan bahwa, siswa banyak beranggapan IPA sulit dipahami. Sehingga momok tersebut yang membuat minat belajar siswa kurang dalam pelajaran IPA, khususnya IPA[10]. Pada sebenarnya momok menakuttkan yang diasumsikan siswa terhadap IPA pada realitasny sebenarnya tidak menjadi pemahaman yang dapat diterima sepenuhnya, karena bisa anggapan sulit tersebut muncul karena rendahnya aspek perilaku (behavior) siswa dalam menyikapinya, misalnya sikap negatif, minat dan motivasi yang rendah, ataupun rendahnya kedisiplinan siswa terhadap objek pelajaran IPA.

Berdasarkan uraian tersebut dapat disimpulkan bahwa salah satu solusi untuk meningkatkan efektivitas siswa terhadap pelajaran IPA adalah dengan mendorong penerapan karakter disiplin siswa terhadap pelajaran IPA pada setiap siswa (khususnya IPA-). Karena dengan disiplin kegiatan anak bangsa (peserta didik) menjadi lebih meningkat kualitasnya karena lebih peka terhadap pengaruh sesuatu yang sifatnya negatif, selain itu kegiatan yang dilaksanakan bisa berjalan secara efektif dan efisien [11]. Adanya korelasi positif antara penerapan disiplin dengan Pembelajaran IPA, maka dalam hal ini dibuatlah sebuah pemelitian dengan tujuan agar mengetahui bagaimana disiplin siswa terhadap IPA. Fokus penelitian ini menganalisis disiplin siswa terhadap IPA berdasarkan 3 indikator disiplin siswa yang dianggap relevan, yaitu: (1) disiplin dalam masuk sekolah, (2) disiplin mengikuti pelajaran IPA di Sekolah, dan (3) disiplin mengerjakan tugas IPA.

\section{METODE PENELITIAN}

Penelitian ini menganalisis dan mendeskripsikan siswa tentang bagaimana kedisiplinan siswa pada mata pelajaran IPA. Fokus peneltian ini merujuk terhadap disiplin sisiwa terhadap Pelajaran IPA. Pendekatan penelitian yang digunakan dalam penelitian ini adalah pendekatan kuantitatif. Secara umum penelitian kuantitatif lebih menekankan pada keluasan informasi, sehingga penelitian ini tepat digunakan untuk populasi yang luas dengan variabel yang terbatas [12]. Sedangkan dalam prosesnya penelitian ini mengadopsi metode survey sebagai pelaksaaan di lapangan. Rancangan survey (survey design), peneliti mendeskripsikan secara kuantitatif (angka) beberapa kecenderungan, perilaku, atau opini dari suatu populasi dengan meneliti sampel populasi tersebut [13]. Nantinya dari pelaksanaan jalannya proses penelitian tersebut akan didapatkan data penelitian yang merujuk tentang disiplin siswa terhadap IPA .

Responden penelitian ini berasal dari siswa/i (peserta didik) pada tingkat Sekolah Menengah Negeri di Kabupaten Muaro Jambi. Jumlah sampel penelitian yang digunakan adalah 187 Peserta didik di Kabupaten Muaro Jambi. Teknik pengambilan data dilakukan dengan metode total sampling, sehingga keseluruhan jumlah siswa (187 siswa) akan ditarik kesimpulan terkait hasil data penelitiannya.

Hasil data ini berasal dari pemberian angket (kuesioner) penelitian kepada seluruh siswa. Angket (kuesioner) ini merupakan instrumen yang digunakan dalam penelitian ini. Angket yang digunakan adalah 
“disiplin siswa terhadap IPA". Angket ini mengukur kedisiplinan siswa terhadap objek pelajaran IPA . Angket ini terdiri dari 14 pernyataan, baik pernyataan positif dan pernyataan negatif. Fokus pengukuran disiplin siswa terhdap IPA didasarkan 3 indikator berikut: (1) disiplin masuk sekolah, (2) disiplin dalam mengikuti pelajaran IPA, dan (2) disiplin mengerjakan tugas IPA.

Tabel 1. Indikator disiplin terhadap IPA

\begin{tabular}{|c|c|c|}
\hline No. & Indikator & $\begin{array}{c}\text { Jumlah } \\
\text { Pernyataan }\end{array}$ \\
\hline 1. & Disiplin masuk sekolah & 3 \\
\hline 2. & Disiplin mengikuti pelajaran IPA & 4 \\
\hline 3. & Disiplin mengerjakan tugas IPA & 7 \\
\hline
\end{tabular}

Skala penilaian pada angket disiplin siswa terhadap IPA pada penelitian ini menggunakan skala likert. Terdapat 5 skala penilaian pada setiap pernyataan angket ini. Sistem penilaian pada angket ini dibagi menjadi 5 kateogri penilaian disiplin, sietem penelitian ini berlaku sebagai berikut: Sangat Tidak Baik (STB) $=1$, Tidak Baik $(\mathrm{TB})=2$, Cukup $(\mathrm{C})=3$, Baik $(B)=4$, dan Sangat Baik $(\mathrm{SB})=5$. Selanjutnya dalam proses pengolahan dan anlisis data penelitian menggunakan statistik deskriptif. Statistik ini akan menggambarkan bagaimana kedisiplinan siswa terhadap IPA.

\section{HASIL DAN PEMBAHASAN}

\subsection{Disiplin Masuk Sekolah}

Berikut ini Tabel 2 adalah hasil statistik disiplin siswa terhadap IPA berdasarkan indikator disiplin dalam masuk sekolah. Tabel 2 ini menggambarkan kategori disiplin siswa terhadap IPA. Berikut hasil tabelnya.

Tabel 2. Disiplin masuk Sekolah

\begin{tabular}{|c|c|c|c|c|c|c|c|}
\hline \multicolumn{3}{|c|}{ Klasifikasi } & \multirow{2}{*}{$\%$} & \multirow{2}{*}{$\begin{array}{l}\text { Standar } \\
\text { Deviasi }\end{array}$} & \multirow{2}{*}{ Mean } & \multirow{2}{*}{ Modus } & \multirow{2}{*}{ Mediar } \\
\hline Rentang & Disiplin & Jumlah & & & & & \\
\hline $3.0-5,4$ & Sangat Tidak Baik & 1 & 0,5 & \multirow{5}{*}{0,8} & \multirow{5}{*}{4,5} & \multirow{5}{*}{5} & \multirow{5}{*}{5} \\
\hline $5,5-7,8$ & Tidak Baik & 6 & 3,2 & & & & \\
\hline $7,9-10,2$ & Cukup & 12 & 6,4 & & & & \\
\hline $10,3-12,6$ & Baik & 39 & 20,9 & & & & \\
\hline $12,7-15,0$ & Sangat Baik & 129 & 69,0 & & & & \\
\hline \multicolumn{2}{|r|}{ Total } & 187 & 100 & & & & \\
\hline
\end{tabular}

Tabel 2 menunjukkan bahwa disiplin masuk kelas menunjukkan kedisplinan yang sangat baik. Berdasarkan tabel 2 menunjukkan bahwa nilai kategori paling dominan berada pada kategori disiplin "sangat baik" dengan nilai persentase 69\% (129 dari 187 siswa). Selain itu tabel 2, juga menunjukkan kategori disiplin secara berturut sebagai berikut: disiplin "baik" dengan 39\% (39 siswa), disiplin cukup dengan 6,4\% (12 siswa), disiplin "tidak baik" dengan 3,2\% (6 siswa), dan terakhir disiplin dengan kategori "sangat tidak baik" dengan persentase $0,5 \%$ ( 1 siswa). Maka, berdasarkan hasil nilai dominan pada tabel 2 menunjukkan bahwa disiplin siswa terhadap IPA berada pada disiplin positif yang sangat baik.

Displin masuk sekolah dimaknai sebagai kebiasaan dan perilaku siswa yang konsisten dan ditunjukkan dari tanggung jawabnya senantiasa disiplin dalam perihal keberangkatannya masuk kelas. Hal itu dilihat dari aspek siswa yang selalu berangkat setiap hari dan tepat waktu. Indikator ini dianggap penting, karena salah satu prinsip siapnya siswa dalam mengikuti pembelajaran di kelas khususnya pelajaran IPA, di awali terlebih dahulu bagaimana kedisiplinan siswa saat masuk sekolah. Karena siswa yang masuk sekolah dengan tanggung jawab yang baik menunjukkan karakter yang baik pula (karakter positif), dan berlaku sebailiknya siswa yang kurang/tidak disiplin akan menunjukkan karakter negatif. . Pendidikan karakter disiplin sangat penting untuk diperhatikan dalam rangka membina karakter seseorang, khususnya siswa [14]. Sehingga karakter yang baik ini juga akan mendorong kedisiplinan siswa terhadap IPA. khususnya mendorong siswa dalam berdisiplin dengan tumbuh dari diri sendiri untuk senantiasa masuk sekolah dengan penuh tanggung jawab dan siap dalam mengikuti proses pembelajaran di kelas. Disiplin sekolah apabila dikembangkan dan diterapkan dengan baik, konsisten, dan konsekuen akan berdampak positif bagi kehidupan dan perilaku siswa [15]. 


\subsection{Disiplin Mengikuti Pelajaran IPA di Sekolah}

Tabel 3. Berikut merupakan hasil disiplin siswa terhadap IPA, yang ditinjau berdasarkan indikator disiplin dalam mengikuti pelajaran IPA di Sekolah. Berikut adalah hasil selengkapnya

Tabel 3. Disiplin Mengikuti Pelajaran IPA

\begin{tabular}{|c|c|c|c|c|c|c|c|}
\hline \multicolumn{3}{|c|}{ Klasifikasi } & \multirow{2}{*}{$\%$} & \multirow{2}{*}{$\begin{array}{c}\text { Standar } \\
\text { deviasi }\end{array}$} & \multirow{2}{*}{ Mean } & \multirow{2}{*}{ Modus } & \multirow{2}{*}{ Median } \\
\hline Rentang & Disiplin & Jumlah & & & & & \\
\hline $4,0-7,3$ & Sangat Tidak Baik & 0 & 0 & \multirow{5}{*}{0,98} & \multirow{5}{*}{3,9} & \multirow{5}{*}{5} & \multirow{5}{*}{4,0} \\
\hline $7,3-10,4$ & Tidak Baik & 16 & 8,6 & & & & \\
\hline $10,5-13,6$ & Cukup & 50 & 26,7 & & & & \\
\hline $13,7-16,8$ & Baik & 54 & 28,9 & & & & \\
\hline $16,9-20,0$ & Sangat Baik & 67 & 35,8 & & & & \\
\hline \multicolumn{2}{|r|}{ Total } & 187 & 100 & & & & \\
\hline
\end{tabular}

Tabel 3 menunjukkan disiplin siswa terhadap IPA pada indikator disiplin mengikuti peljaran IPA di Sekolah. Hasil analisis deskriptif tersebut disimpulkan bahwa karakter disiplin siswa paling dominan terdapat pada ketegori displin baik dengan persentase 33,6\% (63 siswa). sedangkan hasil selengkapnya antara lain: kategori sangat baik $(31,6 \%)$, kategori cukup $(19,8 \%)$, kategori tidak baik $(8,6 \%)$, dan kategori sangat tidak baik $(6,4 \%)$. Maka, dapat disimpulkan berdasarkan hasil tersebut sikap disiplin siswa pada indikator ini tergolong sabagai disiplin positif atau baik.

Disiplin dalam mengikuti pelajaran IPA merupakan perilaku siswa dalam mengikuti proses pembelajaran IPA. Perilaku ini ditunjukkan bagaimana kecenderungan dan kebiasaan siswa dalam mengikuti pelajaran IPA, yang umumnya siswa menunjukkan repson sungguh-sungguh, aktif, dan memiliki minat dan motivasi yang baik terhadap pembelajaran IPA yang diberikan. Kecenderungan minat belajar adalah dorongan dan kemauan siswa siswa dalam proses belajar dan berusaha mengetahui dan memahami materi [16]. Kemauan tersebut dapat dimunculkan oleh siswa ketika siswa memiliki kedisiplinan dalam memahami tanggung jawabnya sebagai tugas siswa dalam mengikuti proses pembelajaran dengan baik.

Dari hasil penelitian menunjukkan sikap disiplin yang sangat baik, dengan dibuktikan data disiplin paling dominan berada pada kategori sangat baik dengan nilai 35,8\% (67 siswa). dengan demikian hasil tersebut menunjukkan displin positif terhadap proses kegiatan pembelajaran IPA pada siswa, yang ditunjukkan sebagian besar siswa terlibat aktif dan berminat dalam proses kegiatan belajar IPA. Pembelajaran dikatakan berhasil dan berkualitas apabila seluruhnya/sebagian peserta didik terlibat secara aktif, bak secara fisik, mental dan sosial dalam proses pembelajaran [17].

\subsection{Disiplin Mengerjakan Tugas IPA} berikut.

Untuk hasil indikator disiplin mengerjakan tugas IPA. hasil selengkapnya terlampir pada tabel 4

Tabel 4. Disiplin Megerjakan Tugas IPA

\begin{tabular}{|c|c|c|c|c|c|c|c|}
\hline \multicolumn{3}{|c|}{ Klasifikasi } & \multirow{2}{*}{$\%$} & \multirow{2}{*}{$\begin{array}{l}\text { Standar } \\
\text { deviasi }\end{array}$} & \multirow{2}{*}{ Mean } & \multirow{2}{*}{ Modus } & \multirow{2}{*}{ Median } \\
\hline Rentang & Disiplin & Jumlah & & & & & \\
\hline $7,0-12,6$ & Sangat Tidak Baik & 1 & 5 & & & & \\
\hline $12,7-18,2$ & Tidak Baik & 7 & 3,7 & & & & \\
\hline $18,3-23,8$ & Cukup & 43 & 23,0 & 0,83 & 3,9 & 4,0 & 4,0 \\
\hline $23,9-29,4$ & Baik & 86 & 46,0 & & & & \\
\hline $29,5-35,0$ & Sangat Baik & 50 & 26,7 & & & & \\
\hline Total & & 187 & 100 & & & & \\
\hline
\end{tabular}

Berdasarkan uraian hasil data pada tabel 4 terkait disiplin siswa dalam mengerjakan tugas IPA menunjukkan hasil yang positif, hal ini didukung kateogi sikap disiplin paling dominan berada pada kategori "baik" dengan persentase 46\% (86 siswa). selain itu secara berturut hasil disiplin siswa terhadap IPA berdasarkan kategori disiplin yag dominan sampai yang tidakdisimpulkan sebagai berikut: 2 . Disiplin "sangat baik" = 26,7\% (50 siswa), 3. Disiplin "cukup" dengan 23\% (43 siswa), 4. Disiplin "tidak baik" dengan 3,7\% (7 siswa), dan terakhir ke-5 kategori disiplin "sangat tidak baik" dengan 0,5\% (1 siswa). berdasarkan hasil 
tersebut menunjukkan sikap disiplin siswa terhadap IPA berdasarkn indikator "disiplin mengerjakan tuga IPA" memiliki kategeori disiplin positif terhadap IPA.

Disiplin dalam mengerjakan tugas IPA (sains) dapat dimaknai bahwa setiap siswa tidak memiliki ketergantungan yang negatif dalam mengerjakan tugas sains yang diberikan oleh gurunya [18]. Sehingga kecenderungan yang timbul adalah ketergantungan positif terhadap IPA, yang ditunjukkan dari kemandirian siswa dalam mengerjakan tugas IPA. Sejalan dengan hal tersebut hasil penelitian ini juga menunjukkan disiplin siswa dengan karakter positif dan kategori yang baik. diperkuat dari nilai kateogri disiplin menunjukkan kategori baik dengan persentase 46\% (86 siswa) dan paling dominan dari kategori lainnya.

\section{KESIMPULAN}

Berdasarkan hasil penelitian ini dapat disimpulkan bahwa kedisiplinan siswa terhadap objek Pelajaran IPA di SMP Negeri di wilayah Kabupaten Muaro Jambi menunjukkan hasil yang sangat baik. Berdasarkan uraian analisis statisik pada tabel hasil menunjukkan disiplin yang positif. Hal tersebut dibuktikan dari nilai kategori dominan yang terdapat pada setiap indikator (tabel 2, tabel 3, dan tabel 4). Berikut kategori dominan pada setiap indikator disiplin siswa terhadap IPA: (1) disiplin dalam masuk sekolah menunjukkan kategori sikap disiplin sangat baik dengan 69\% (129 dari 187 siswa), (2) disiplin mengikuti pelajaran IPA di sekolah dominan menunjukkan pada kategori disiplin sangat baik dengan 35,8\% (67 dari 187 sisswa), dan (3) disiplin dalam mengerjakan tugas IPA menunjukkan kategori disiplin baik dengan $46 \%$ (86 siswa). Maka, dari hasil tersebut dapat disimpulkan disiplin siswa terhadap IPA menunjukkan disiplin positif dengan kategori sikap disiplin yang sangat baik.

\section{UCAPAN TERIMAKASIH}

Hal ini peneliti akan menguapkan terimakasih kepada seluruh pihak yang telah mendukung dan membantu peneliti sehingga penelitian ini dapat terlakasana dengan lanar dan baik.

\section{REFERENSI}

[1] M. Munafrizal. The Implementation Of The Right To Education In Indonesia*. Indonesia Law Review. vol 1: Pp 51-68. 2015

[2] Astalini, D. A. Kurniawan., R. Perdana. \& D. Kurniasari. Identification of Student Attitudes toward Physics Learning at Batanghari District High School. The Educationl Review, USA, Vol 2 No. 9, Pp 475-484. 2018. http://dx.doi.org/10.26855/er.2018.09.003

[3] D. A. Kurniawanl., Astalini, N. Kurniawan., \& H. Pathoni. Analisis Korelasi Sikap Siswa dan Disiplin Siswa terhadap IPA pada Siswa SMP Provinsi Jambi. Jurnal Pendidikan Fisika dan Keilmuan (JPFK), Vol 5 No 2, Pp 5975. 2019

[4] N. Hidayati. Pembelajaran Discovery Disertai Penulisan Jurnal Belajar Untuk Meningkatkan Kemampuan Kerja Ilmiah Siswa Kelas VIII 1 SMP Negeri 1 Probolinggo. Jurnal Penelitian Pendidikan IPA, Vol 1 No 2, Pp 52-61. 2016

[5] Sudewo. Best Practice Character Building, Menuju Indonesia Lebih Baik. Jakarta Selatan: Republika, 2011

[6] Astalini, H. Pathoni., D. A. Kurniawan., \& Kurniawan, N. The Correlation Between Attitudes and Discipline Toward Sciece of Secondary School. Jurnal Pendidikan Sains. Vol 7 No 1, Pp 9 -14. 2019

[7] Z. Aslianda., \& N. Nurhaidah. Hubungan disiplin belajar terhadap hasil belajar siswa kelas IV Sekolah Dasar Negeri 18 Banda Aceh. Jurnal Ilmiah Mahasiswa Pendidikan Guru Sekolah Dasar, Vol 2 No 1, Pp 236-243. 2017

[8] D. Bestari., D. Yulianti. \& P. Dwijananti. Pembelajaran Menggunakan SEA Berbantu Games Untuk Mengembangkan Karakter Siswa SMP. Unnes Physics Education Journal, Vol 3 No 1, 2014

[9] R. Astuti., S. Widha., dan S. Suciati. Pembelajaran IPA Dengan Pendekatan Keterampilan Proses Sains Menggunakan Metode Eksperimen Bebas Termodifikasi Dan Eksperimen Terbimbing Ditinjau Dari Sikap Ilmiah Dan DisiplinBelajar Siswa. Jurnal Inkuiri. Vol. 1, No . 1, Pp 51-59. 2012

[10] A. Widiyatmoko. Pengembangan Perangkat Pembelajaran IPA dengan Pendekatan Physics-Edutaiment Berbantuan CD Pembelajaran Interaktif. Journal Of Primary Education, Vol 1 No 1, pp 38-44. 2012

[11] H. A. T. Rusyan. Membangun Disiplin Karakter Anak Bangsa. Jakarta : PT. Pustaka Dinamika, 2014

[12] Sugiono. Metode Penelitian Kuantitatif, Kualitatif dan Kombinasi (Mixed Methods). Bandung : Penerbit Alfabeta, 2016

[13] J. W. Creswell. Educational Research: Planning, Conducting and Evaluating Quantitative and Qualitative Research (4th ed.). Boston: Edwards Brothers, Inc. 2012 
[14] W. Wuryandani., B. Maftuh., \& D. Budimansyah. Pendidikan Karakter Disiplin Di Sekolah Dasar. Cakrawala Pendidikan. Vol 33 No 2, Pp 286-295. 2014

[15] L. S. Hadianti. Pengaruh Pelaksanaan Tata Tertib Sekolah Terhadap Kedisiplinan Belajar Siswa. Jurnal Pendidikan Universitas Garut. Vol 2 No 1, Pp 1-8. 2008

[16] A. Budiono. \& L. T. Antika. Review $\pi$ : What Is The Description Of Students' Interest In Physics?. Jurnal Pena Sains. 5(2), 115-120. 2018

[17] M. Febriana., H. Al Asya'ari., B. Subali., \& A. Rusilowati. Penerapan Model Pembelajaran Inquiry Pictorial Riddle Untuk Meningkatkan Keaktifan Siswa. Jurnal Pendidikan Fisika dan Keilmuan (JPFK), Vol 4 No 2, Pp 612. 2018

[18] D. A. Kurniawan., Astalini, \& N. Kurniawan. Sikap SIswa Terhadap Pelajaran IPA di SMP Kabupaten Muaro Jambi Provinsi Jambi. Curricula: Journal of Teaching and Learning, Vol 4 No 3, Pp 111-127. 2019. Doi:http://dx.doi.org/10.22216/jcc.2019.v4i3.4150 